\title{
Consumption of specific tourist products - the value of participation in mega-event and its influence in shaping visitor loyalty to a destination
}

\author{
Agata Niemczyk \\ Cracow University of Economics \\ Poland \\ agata.niemczyk@uek.krakow.pl \\ Renata Seweryn \\ Cracow University of Economics \\ Poland \\ renata.seweryn@uek.krakow.pl
}

\begin{abstract}
This paper aims to answer the question of whether a mega-event can act as an incentive for tourists to return to a previously visited destination. In order to find an answer to this research question, hypotheses were proposed with the aim of revealing dependencies between selected aspects of consumption of tourist products such as UEFA European Football Championships (EURO). The pertinent analyses were performed on the basis of research conducted in Krakow in 2012. In order to verify six of the main hypotheses of a lack of relationships between variables $X_{i}$, Spearman's rank correlation coefficient was used wherever possible; in other cases the test $\mathrm{c}^{2}$ was used (and to calculate the strength of correlation, the V-Cramer coefficient was used). The analyses carried out confirmed prior theoretical constatations that satisfaction with a stay in a destination concurrently hosting a mega-event translates into improvement of that destination's image and greater loyalty among tourists; and that the better the image of a mega-event venue, the stronger the effect of the tourist's loyalty towards that place. The research shows also that the higher the frequency of visits to the venue of a mega-event, the longer the time spent in that place.
\end{abstract}

Keywords: tourist consumption, mega-event, tourist satisfaction, emotional loyalty, behavioural loyalty

JEL classification: C49, D01, D11, D12, Z11, Z13

\section{INTRODUCTION}

Market entities essentially exist to meet their own needs. In the contemporary world, these needs are changing rapidly and are highly diverse, not only due to the extensive heterogeneity of the institutions and people who report them, but also in view of their intrinsic nature. The most basic entity on the market is a consumer who, representing the most basic level of demand, signals the need for various goods and 
services, including those which satisfy her/his needs during her/his leisure time. Given that in the future there will be a greater requirement for more experiences, and that in their search for different experiences consumers will increasingly look for a deepening experiential value and more intense experiences (European Travel Commission [ETC], 2006, p. 6), we may assume that some of the most sought-after offers on the tourism market will be events of various types - sporting, cultural or entertainment. The creators of products answering this description are the various institutions that strive to satisfy a tourists visiting a particular destination and taking part in a particular event. It is therefore reasonable to assume that a guest's level of satisfaction with a destination should translate into a form of continued loyalty. Given the saturation of the tourism market, destinations tend to take special measures to win tourists' loyalty, the more so that, according to some forecasts, 'with fewer returning tourists it may be difficult for some destinations to build any form of future loyalty' (Ibid., 2006, p. 5).

With regard to the above, the following question was formulated and empirically verified: Can events, especially large-scale events, offer sufficient attraction to persuade a tourist to return to a previously visited destination?

The relevant literature describes the subject of mega-events in contexts including management, marketing, economic impact, and consequences for local residents (Moscardo, 2007). The thrust of this paper will be to show the extent to which organisation of a mega-event (in this case: a sporting event) in a given area can contribute to tourist revisits to that destination. Participation in a mega-event creates a certain value for a tourist, which is understood as the positive difference between benefits accrued and costs incurred (Seweryn, 2012, p. 25). The only question is whether this value is significant enough to evolve into any form of loyalty. Naturally, the research issue thus defined is not a problem apart from the areas of research into mega-events already addressed in the literature, but is closely related to them, as it offers, inter alia, insight into ways of managing such ventures so as to generate economic benefits.

The basis for the empirical data gathered was the results of the survey carried out as statutory research under the supervision of Professor Jadwiga Berbeka at the Department of Tourism at the Cracow University of Economics (CUE). This survey was conducted on a representative sample of 890 tourists who visited Krakow in connection with the UEFA European Football Championships in June 2012. Thus the aim of this analysis will be to determine the influence of these tourists' satisfaction with their stay in Krakow on their image of the city and their potential future loyalty to it as a destination.

\section{THE BACKGROUND PICTURE}

Tourist consumption is generally accepted to be the means by which a tourist satisfies his/her individual wants, in this case through the purchase of tourist products. Examples of tourist consumption could include an overnight stay in a hotel, visiting monuments, use of guide or transport services, and participation in cultural or sporting events. The subject who engages in any of these forms of consumption is an individual, a tourist. In other words, a consumer engaging in tourism signals her/his level of demand for tourist products, which take the form of either basic products, e.g. services and objects, or more complex deliverables, such as events, places or tourist routes. In terms of the latter, this paper will focus on events, in particular mega-events.

\section{The importance of mega-events in contemporary tourist consumption}

Broadly speaking, an event is an occasion planned and organised in order to achieve a particular purpose. This purpose determines the type of an event and its participants, as well as the venue, time, and resource 
necessary to stage it. There are many different categories of events. Some interesting typologies are proposed by Mules and Faulkner (1996), Bos (1994), Ritchie (1984, p. 2), Hall (1992, p. 22), Getz (1991; 2008, pp. 411412), and others (e.g. Niemczyk, 2001, pp. 273-274). From among the many events staged, those that attract the greatest attention tend to be the biggest. These are referred to as mega-events, and are defined as 'major one-time or recurring events of limited duration, developed primarily to enhance the awareness, appeal and profitability of a tourist destination in the short and/or long term' (Ritchie, 1984, p. 2).

The foremost expert on the subject of events as an important motivator of tourism ('event tourism') ${ }^{1}$ is Getz, whose publications include a broad review of the literature in this field (e.g. Getz, 2008, pp. 409-411; 2010). He suggests taking a wider view of the phenomenon of events, and includes in his deliberations both organisers and consumers. According to his research,

'a special event is a onetime or infrequently occurring event outside the normal program or activities of the sponsoring or organizing body. To the customer, a special event is an opportunity for leisure, social, or cultural experiences outside the normal range of choices or beyond the everyday experience' (Getz, 1991, p. 44).

Getz (2008, p. 405) also emphasises that 'event tourism is an important and rapidly growing segment of international tourism'.

Burns, Hatch and Mules note that the scale of an event is measured by the number of participants. They classify a mega-event as 'an event that generally attracts a large number of people, for instance more than 100,000 , involves significant investments and creates a large demand for a range of associated services' (Burns, Hatch, \& Mules, 1986, p. 131). It is assumed that participants in such events spend more money per day than ordinary tourists. However, the level of spending depends on the event profile. Moreover, it has been observed that the most attractive tourist of this sort is the older, more affluent person (Getz, 1994).

Regardless of the definition adopted of an event (mega-event), all authors concur in emphasising the benefits that accrue in the area where the event is held. Among these, they cite the economic effects of such ventures, stressing the long-term consequences for the destination's economy connected with the many associated investments (e.g. Crompton \& McKay, 1994; Burgan \& Mules, 2001; Burns et al., 1986; Getz, 2000; Preuss, 2007). Authors also explicitly mention the social implications of mega-events. Furthermore, Kim, Gursoy and Lee (2006) claim that these types of benefits often prove even more significant than those of an economic nature. Moreover, mega-events offer an invaluable opportunity to promote other tourist functions (Ribeiro et al., 2004, p. 5). They help - as is stressed by Gaworecki (2003, p. 228) - to improve the image of a tourist city, region or even the whole country, and to produce long-term promotional effects.

\section{Destination image}

Image is a critical determinant in the choice of a given destination (Kavaratzis \& Ashworth, 2005; Milman \& Pizam 1995; Dann, 1996). Kotler and Gertner (2002, p. 251) define a destination's image as

'the sum of beliefs and impressions people hold about a place. Images represent a simplification of a larger number of associations and pieces of information connected to a place. They are a product of the mind trying to process and pick out essential information from huge amounts of data for a given place'.

For Murphy, Pritchard and Smith (2000), a destination's image is the sum of the associations and information connected to a destination, which would include multiple components of the destination and 
personal perception. In light of the above, a region's image is understood as the way the destination is truly perceived by its environment.

The first step in building the image of a region is to define its identity. This is the set of fundamental attributes that differentiate a place/region from any other. The image thus plays a secondary role in the region's identity - as the basis for its creation. While identity is internal to the region, its image is external. According to Kotler (1994, p. 279), identity is the way an entity wishes to be perceived by its recipients, while the image is the real picture stored in those recipients' minds. Image is the effect of the impact of the media and of informal messages (Kobus, 2005; San Martin \& del Bosque, 2008, pp. 263-277) that reach recipients. As a subjective category, it is defined by the attributes of the recipients, and their subjective perception of a place. For instance, the image is different for those who have already visited a destination than for those who form it solely on the basis of available information. The perception is also different in the case of a person making her/his first visit to that of someone on a subsequent visit. Finally, the image of a region might be different before and after the visit (Kim \& Morrsion, 2005, pp. 233-247). Thus we should conclude that the image of a place is in some sense the combined result of its identity and the recipient's identity.

\section{Participants' level of satisfaction and potential loyalty after the event}

Organisation of mega-events is not only a chance to raise the prestige of a destination; it also helps build a positive image (Davidson \& Rogers, 2006). Moreover, events are offensive actions, i.e. they attract new visitors. Many of these may prove loyal to the destination - on condition, however, that they are satisfied with their stay, since, logically speaking, this factor (alongside the image) plays a significant role in decisions taken by tourists regarding their choice of their next destination. In this context, that means that the destination they visited in order to attend the event may well become a permanent presence on their map of preferences (Kozak \& Remmington, 2000; Cole \& Scott, 2004; Lau \& McKercher, 2004). Satisfaction thus increases the probability of repeat visits (Doyle, 2000, p. 71), motivating a tourist to return, though it is not an automatic guarantee of such returns. Nonetheless, even if a satisfied tourist never returns to a place s/he enjoyed (for such is the nature of the sector - Eriksson and Vaghult, 2000 - that is tourism), s/he will still recommend it as a destination to other prospective tourists due to the attraction, pride in his/her stay, trust, surprise, or other positive after-feelings.

Satisfaction (and in particular delight) produces emotional loyalty, that is, spreading positive opinions about the destination among family, friends, neighbours, colleagues, Internet users, etc. (Reichheld, 2006, p. 19). A tourist 'advocate' undertakes some of the marketing communication in the area, so creating increased interest in the destination and increased awareness of its existence in the market among prospective tourists. Such (hidden) loyalty is significant when it comes to purchases of selectable products whose price and the perceived risk of making a mistake is high (and these surely include tourist offers). In situations of this nature buyers try to behave consciously and rationally (choosing the product of the highest value), but they also heed their own previous experiences, and feelings of their own and others who have already used the product. Recommendation is a credible guarantee to a tourist that a destination will give him/her, too, high quality value.

It is worth emphasising at this point that the need to build loyalty depends on the level of saturation in the market (Kotler, Armstrong, \& Cunningham, 1999, pp. 608-610). At the development stage there are many potential buyers of a certain product and suppliers, who do not see the need to strive for returning customers - in the place of those who might not wish to come again, they will find new tourists. However, in conditions such as those we are seeing today, i.e. as more and more towns, regions and countries are benefiting more directly from tourism, the individuals visiting them likewise have more destination alternatives 
to choose from. The tourism market is becoming saturated, and highly competitive. The search for new tourists is not only much more difficult but also more expensive; it entails poaching them from rival destinations. Hence, the need to satisfy customers already won over once (e.g. by a mega-event) and to build their loyalty (i.e. defensive attitude) is extremely pressing in current conditions.

Tourist loyalty constitutes one of the strategic assets of a given destination and is the key qualitative intangible resource as well as a driver of development. This is the potential which enables a destination to build a competitive advantage in the contemporary tourist market. Therefore, an awareness of the process of satisfying a customer and the ability to build his/her loyalty are two of the most important marketing competencies.

\section{Modelling tourist satisfaction}

The causes and effects of customer satisfaction have been studied by many scholars attempting to build a relevant model (Fornell, 1992; Fornell et al., 1996). The analyses of the issue are to be found also in tourist publications (Yoon \& Uysal, 2005; Chi \& Qu, 2008). Most theoretical and empirical studies employ the expectancy disconfirmation model (Oliver, 1980), which can be used to define satisfaction and subsequently to forecast loyalty. On the basis of this model it should be assumed that a value of a territorial tourist product, as experienced, that is merely comparable with its value as expected does not contribute significantly to a tourist's satisfaction, since the outcome was as predicted. Satisfaction will not occur unless what a tourist finds there exceeds his/her expectations. It is clear that an important role in the perception of a product and the experience of satisfaction is played by expectations. The key issue here for destinations is not just meeting those expectations but exceeding them.

Prior conceptions of a destination's product are fired by three groups of factors: (1) those related to a tourist consumer herself/himself, (2) those related to the destination, and (3) those generated by the environment (O'Connor, Shewchuk, \& Carney, 1994, p. 33). The first group includes a socio-demographic profile, personality, interests, motivation of a tourist, values professed, and previous experiences. The second group is shaped above all by the marketing communication of the destination, which should be uniform and consistent in order to enable the customer to judge the offer properly and specify viable expectations. For if the content communicated by a destination does not reflect its real possibilities, a 'communication gap' is produced, which will significantly influence dissatisfaction with the stay, generate disappointment or even frustration, and exclude the destination from future decision cycles. The group of external factors, in turn, includes the image of the travel destination, opinions of people accessed by a tourist in the private or public forum, fashion and emulation, media reports generating emotions and attitudes, and 'background noise' (including the competition).

Moreover, there are some expectations of which a tourist is not aware and which s/he cannot fully define, and these, too, plays a significant role in determining satisfaction with a stay at a destination (Gronroos, 2001, p. 90). Hence in the literature related to tourism determinants such as the tourist's own sociodemographic profile or destination image are often included in the cause and effect model. These components are especially useful to travel destinations in the process of planning effective marketing strategies for product positioning, market segmentation, price, advertising or merchandising (Chan et al., 2003).

The final task of research into tourists' satisfaction with their stay at a destination is not only to map action to improve the satisfaction and thus the loyalty of all its visitors, but first of all to select the most valuable customers, i.e. the key accounts. These are the ones in whom it is worth investing a substantial part of the available resources in the conviction that cooperation with them will be the best way to satisfy the destination's long-term ambitions (Cheverton, 2004, p. 6). The objectives here are above all the revenues of 
local tourist and para-tourist entrepreneurs and the local budget, and hence the development of the destination, the strengthening of its market position, and the creation of the best image to bring in long-term profit.

The above considerations invite the conclusion that event organisation has the potential to deliver substantial benefits to tourist destinations. Some specific examples of mega-events are economic and political forums, EXPO exhibitions, and the Olympic Games. Among these, as Getz stresses (2008, p. 411), 'sports as "big business" is an enduring theme in the literature', including most notably the Olympic Games, but also the FIFA World Cup and the UEFA European Football Championships. This paper concentrates on the latter.

\section{METHOD}

During the mega-event that was the EURO UEFA European Football Championships, held from June to July 2012, a survey was conducted in Krakow by the Department of Tourism at the Cracow University of Economics, as a part of a project called The impact of the European Football Championship EURO 2012 in Poland on tourism in Krakow ${ }^{2}$. The survey was completed by 1,526 visitors to the city. 890 of them had come because of EURO 2012, and it is this group that shall be the body of subjects for the analyses in this paper. It should be noted here that the event was organised and hosted jointly by Poland and Ukraine; in Poland the venues were Warsaw, Poznań, Wrocław and Gdańsk. None of the matches took place in Krakow, yet the capital of Małopolska attracted large numbers of tourists and fans due to the fact that two important football teams - the English and the Dutch - were accommodated there, with the Italian team in Wieliczka (some $15 \mathrm{~km}$ from Krakow). With this in mind, a special fan zone, FAN KRAKÓW, was created.

A questionnaire prepared by a team from the Department of Tourism at CUE was used in the research. It was distributed in places attracting the highest concentration of fan tourists, e.g. near the hotels where the teams were accommodated, and also in the FAN KRAKÓW zone, catering outlets in the city, and fan transfer hubs (the main railway station and the airport).

The hypothetical cause and effect model adopted for the analysis in this paper is based on the sixth conception of Oliver (1999, p. 34), i.e. it assumes that satisfaction is the initial stage of the process, and leads to the development of an independent process of loyalty. The answers to the 12 questions (out of the 22 asked) used in the analysis were assigned the following numerical values:

$-X_{1}$ Gender (female = 1, male $=2$ );

$-X_{2}$ Age (under $18=1,19-24=2,25-34=3,35-44=4,45-54=5,55-64=6$, over $65=7$ );

$-X_{3}$ Material status (very poor $=1$, poor $=2$, average $=3$, relatively good $=4$, very good $=5$ );

$-X_{4}$ Professional status (at school $=1$, student $=2$, unemployed for other reasons $=3$, farmer $=4$, bluecollar worker $=5$, white-collar worker $=6$, self-employed $=7$ );

$-X_{5}$ Size of place of residence (village $=1$, town of $<100,000=2$, town of $101,000-500,000=3$, city of $>500,000=4)$;

$-X_{6}$ Frequency of visits to Krakow (first visit $=1$, subsequent visit $=2$ );

$-X_{7}$ Length of stay in Krakow (dependent on team results $=1$, one day = 2, 2-4 days $=3$, about a week = 4, 7-14 days $=5$, over 14 days $=6$ );

$-X_{8}$ Company during stay in Krakow (came alone $=1$, came with a friend/partner $=2$, came with family $=3$, came with group of friends $=4$, came with an organised group $=5$ );

- $X_{9}$ How do you find Krakow in terms of: atmosphere in the city, the fan zone, cultural events, reaching the city, accommodation, catering, entertainment and leisure facilities, museums, getting around, residents (it was agreed that this question fully reflects the level of satisfaction with stay in the city, hence 
it was accepted that a synthetic evaluation of the city should take the following form: dissatisfied $=1$, satisfied $=2$, delighted $=3)^{3}$;

$-X_{10}$ Has your image of Krakow since your visit: deteriorated drastically = 1, deteriorated slightly = 2, not changed $=3$, improved slightly $=4$, improved dramatically $=5$;

$-X_{11}$ Would you like to visit Krakow again? (definitely not = 1; probably not = 2, probably = 3, definitely = 4);

$-X_{12}$ Will you recommend Krakow as a city worth visiting? (definitely not = 1; probably not $=2$, probably $=3$, definitely $=4$ ).

The model recognises 56 path hypotheses linking 12 components (variables $X_{i}$ ). Of these, attention was paid mainly to the following:

1. The higher the level of satisfaction with the stay at the mega-event venue $\left(X_{9}\right)$, the better the image of the place $\left(X_{10}\right)$.

2. The higher the level of satisfaction with the stay at the mega-event venue $\left(X_{9}\right)$, the higher the declarativity of returns there $\left(X_{11}\right)$.

3. The higher the level of satisfaction with the stay at the mega-event venue $\left(X_{\vartheta}\right)$, the stronger the intent to recommend the place $\left(X_{12}\right)$.

4. The better the image of the mega-event venue $\left(X_{10}\right)$, the higher the declarativity of returns there $\left(X_{11}\right)$.

5. The better the image of the mega-event venue $\left(X_{10}\right)$, the stronger the intent to recommend the place $\left(X_{12}\right)$.

6. The higher the declarativity of returns to the mega-event venue $\left(X_{11}\right)$, the stronger the intent to recommend the place $\left(X_{12}\right)$.

As the majority of variables $X_{i}$ are qualitative features, in order to verify hypotheses of a lack of relationships (dependencies) between them, Spearman's rank correlation coefficient was used wherever possible; in other cases the test $\chi^{2}$ was used (and to calculate the strength of correlation, the V-Cramer coefficient was used). The level commonly used in economic studies, $p=0.05$, was accepted as significance.

\section{RESULTS AND DISCUSSION}

The majority of the research group were men, aged 25-34, with good material status, professionally active, living in larger urban agglomerations (Table 1). A significant percentage of respondents were nationals of Great Britain, followed by Italy and Poland. Israeli nationals were the least numerous group of respondents.

Table 1

Socio-demographic characteristics of visitors to Krakow for EURO 2012

\begin{tabular}{|c|c|c|}
\hline \multicolumn{2}{|c|}{ Specification } & per cent \\
\hline \multirow{3}{*}{ Gender } & 1 & 2 \\
\cline { 2 - 3 } & male & 82.3 \\
\hline \multirow{5}{*}{ Age } & female & 17.7 \\
\cline { 2 - 3 } & under 18 & 2.3 \\
\cline { 2 - 3 } & $19-24$ & 32.3 \\
\cline { 2 - 3 } & $25-34$ & 43.2 \\
\cline { 2 - 3 } & $35-44$ & 15.1 \\
\cline { 2 - 3 } & $45-54$ & 5.7 \\
\cline { 2 - 3 } & $55-64$ & 1.2 \\
\cline { 2 - 3 } & over 65 & 0.2 \\
\hline
\end{tabular}




\begin{tabular}{|c|c|c|}
\hline \multicolumn{2}{|r|}{1} & 2 \\
\hline \multirow{5}{*}{ Material status } & very good & 20.2 \\
\hline & relatively good & 47.4 \\
\hline & average & 29.1 \\
\hline & rather poor & 2.1 \\
\hline & very poor & 1.2 \\
\hline \multirow{7}{*}{ Professional status } & white-collar worker & 38.6 \\
\hline & blue-collar worker & 20.6 \\
\hline & self-employed & 15.8 \\
\hline & student & 18.9 \\
\hline & at school & 2.7 \\
\hline & unemployed for other reasons & 2.7 \\
\hline & farmer & 0.7 \\
\hline \multirow{4}{*}{$\begin{array}{l}\text { Size of place of } \\
\text { residence }\end{array}$} & village & 10.9 \\
\hline & town of $<100,000$ & 22.9 \\
\hline & town of $101,000-500,000$ & 35.2 \\
\hline & city of $>500,000$ & 31.0 \\
\hline \multirow{4}{*}{ Country of residence } & Great Britain & 30.0 \\
\hline & Italy & 18.1 \\
\hline & Poland & 17.4 \\
\hline & other & 34.5 \\
\hline
\end{tabular}

Source: Authors' own compilation based on research conducted by the Department of Tourism at the Cracow University of Economics in 2012.

The results of the empirical research showed significant dependencies in consumption of the tourist product that was the sporting mega-event, and thus also verified all six of the main hypotheses (Figure 1).

What should be stressed above all is the positive dependency between satisfaction with the stay at the destination where the mega-event was held and improvement in the image of that place $\left(r_{s}=0.234\right)$. The analyses carried out also confirmed prior theoretical constatations that the higher the level of satisfaction with the stay at the mega-event venue, the stronger the loyalty towards that place would be. The degree of dependency in the case of behavioural loyalty (tendency to return) equals $r_{s}=0.196$, and in the case of emotional loyalty (the intention to recommend the destination to other tourists) is even higher, at $r_{s}=0.238$. In addition, the study proved that the better the image of a mega-event venue, the stronger the effect of the tourist's loyalty towards that place (Spearman's rank coefficient for the intent to visit Krakow again is 0.170, and for declaration of the intention to spread a positive opinion of the city 0.211 ). The strongest dependency, however, was observed between variables describing the loyalty of tourists towards the mega-event venue $\left(r_{s}=0.54\right)$. That accentuates the interplay between behavioural and emotional loyalty - hence, the more willing a tourist is to visit the place again himself/herself, the more willing s/he is to recommend the place to prospective tourists, and vice versa.

Of the remaining 15 path hypotheses presented in Figure 1, 14 were dismissed. This means that none of the following: frequency of visits, length of stay or companions on the trip, influence substantially satisfaction with the consumption of a destination's product, where the destination is the venue for a mega-event. These variables are not interdependent with change in the image of a destination or loyalty towards it. On the other hand, it is worth noting that the higher the frequency of visits to the venue of a mega-event, the longer the time spent in that place (positive correlation coefficient), and the strength of dependency measured with V-Cramer's coefficient equals 0.201. 


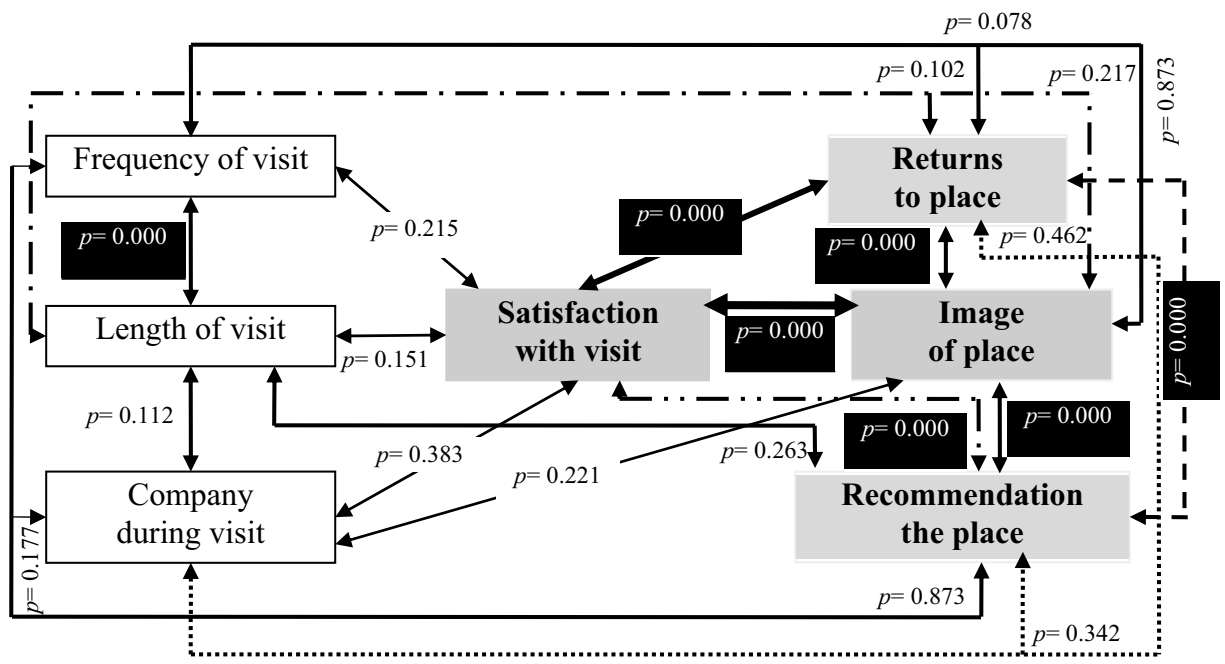

$\mathrm{p}$ - level of dependency significance

$\mathrm{V}-\mathrm{V}$-Cramer's coefficient

$r_{s}$ - Spearman's rank coefficient

Figure 1. Dependencies between the analysed variables $X_{i}$

Source: Authors' own compilation.

Verification of the other 35 path hypotheses, i.e. analysis of the impact of socio-demographic variables of tourists visiting Krakow for EURO 2012 on the frequency of their visits, length of stays, satisfaction with the visits, image evaluation, and also declared loyalty, reveals no significant dependency in this respect connected with tourist gender or age (Table 2).

Table 2

Test probability $p$ for dependencies between satisfaction with stay, change in the image of Krakow, intention to visit the city again and recommend the city, and tourists' socio-demographic profile

\begin{tabular}{|c|c|c|c|c|c|}
\hline Variables $\left(X_{i}\right)$ & Gender $\left(X_{1}\right)$ & Age $\left(X_{2}\right)$ & $\begin{array}{l}\text { Material status } \\
\qquad\left(X_{3}\right)\end{array}$ & $\begin{array}{c}\text { Professional } \\
\text { status } \\
\left(X_{4}\right)\end{array}$ & $\begin{array}{l}\text { Size of place of } \\
\text { residence }\left(X_{5}\right)\end{array}$ \\
\hline 1 & 2 & 3 & 4 & 5 & 6 \\
\hline $\begin{array}{l}\text { Frequency of visits to Kra- } \\
\text { kow }\left(X_{6}\right)\end{array}$ & $\begin{array}{c}\mathbf{0 . 0 0 1 7 *} \\
(V=0.105)\end{array}$ & 0.9325 & 0.7823 & 0.4669 & 0.7079 \\
\hline $\begin{array}{l}\text { Length of stay in Krakow } \\
\left(X_{7}\right)\end{array}$ & 0.7021 & 0.9981 & $\begin{array}{c}\mathbf{0 . 0 0 5 3} \\
(V=0.113)\end{array}$ & 0.2803 & 0.2109 \\
\hline $\begin{array}{l}\text { Company during stay in } \\
\text { Krakow }\left(X_{8}\right)\end{array}$ & $\begin{array}{c}\mathbf{0 . 0 0 0 0} \\
(V=0.214) \\
\end{array}$ & $\begin{array}{c}\mathbf{0 . 0 0 0 0} \\
(V=0.152) \\
\end{array}$ & 0.4686 & $\begin{array}{c}\mathbf{0 . 0 0 5 1} \\
(V=0.113) \\
\end{array}$ & 0.2440 \\
\hline $\begin{array}{l}\text { Satisfaction with stay in } \\
\text { Krakow }\left(X_{q}\right)\end{array}$ & 0.6407 & 0.8798 & $\begin{array}{c}\mathbf{0 . 0 0 1 4} \\
\left(r_{s}=-0.103\right)\end{array}$ & 0.0827 & $\begin{array}{c}\mathbf{0 . 0 1 9 9} \\
(V=0.092) \\
\end{array}$ \\
\hline $\begin{array}{l}\text { Change in the image of } \\
\text { Krakow }\left(X_{10}\right)\end{array}$ & 0.0943 & 0.3468 & $\begin{array}{c}\mathbf{0 . 0 0 2 0} \\
\left(r_{s}=-0.107\right)\end{array}$ & 0.0570 & $\begin{array}{c}\mathbf{0 . 0 0 1 5} \\
(V=0.109)\end{array}$ \\
\hline
\end{tabular}




\begin{tabular}{|l|c|c|c|c|c|}
\hline \multicolumn{1}{|c|}{1} & 2 & 3 & 4 & 5 & 6 \\
\hline $\begin{array}{l}\text { Intention to visit Krakow } \\
\text { again }\left(X_{l l}\right)\end{array}$ & 0.0794 & 0.6371 & $\begin{array}{c}\mathbf{0 . 0 0 9 3} \\
\left(r_{s}^{=}-0.087\right)\end{array}$ & $\begin{array}{c}\mathbf{0 . 0 0 0 0} \\
(V=0.166)\end{array}$ & $\begin{array}{c}\mathbf{0 . 0 0 2 9} \\
(V=0.097)\end{array}$ \\
\hline $\begin{array}{l}\text { Declaration to recommend } \\
\text { Krakow }\left(X_{12}\right)\end{array}$ & 0.9563 & 0.7763 & $\begin{array}{c}\mathbf{0 . 0 1 9 9} \\
\left(r_{s}=-0.078\right)\end{array}$ & $\begin{array}{c}\mathbf{0 . 0 0 1 1} \\
(V=0.125)\end{array}$ & 0.0560 \\
\hline
\end{tabular}

* In bold: Critical dependencies, i.e. those whose test probability $p$ is less than 0.05 .

Source: Authors' own compilation.

Age, and even more so gender, determine only the choice of fellow-travellers to the area of the megaevent venue. The latter variable is also interdependent on the professional status of the participating tourist, as is loyalty - both behavioural and emotional. The size of the place of residence, in turn, affects the level of satisfaction with the stay at the mega-event venue, change in the image of the place, and the likelihood of repeat visits. However, it must be stressed that a negative dependency occurs between the tourist's place of residence and his intention to visit the mega-event venue again. This means that the larger the tourist's place of residence, the less likely s/he is to be interested in returning to areas of greater visitor concentration. The material status of tourists visiting a mega-event venue has significant correlations with the greatest number of variables. That is, the better the visitor's financial condition, the longer her/his stay in the destination will be, yet the lower the level of satisfaction. With wealth, the image of a destination suffers; richer tourists show a lesser tendency to return and are less willing to recommend the place to other tourists. These statements would seem accurate given that a tourist of a greater material means has higher expectations and demands, and it is therefore more difficult for a destination, as a conglomerate of many products of a large number of local players, to meet them.

\section{CONCLUSION}

The research problem, discussed in this paper, aimed to determine whether a mega-event can generate customer loyalty to a tourist destination. In light of the findings made, the answer to this question is positive. As such, local players should take enterprising action to attract tourists by organising such events. Care should be taken in this regard to shape expectations accurately and to satisfy them with appropriate value in the stay at the destination. The second task is the conduct of pertinent study of incoming participating tourist movements. Yet few tourist destinations in Poland take any steps to gauge the level of satisfaction of their visitors, and fewer still include the results of such measures in planning their development strategy and auxiliary operational action. There are a number of reasons that may be mooted for this.

Firstly, institutions managing the destination and the local sector have not yet realised the benefits of tourists' satisfaction and their loyalty, not only for service providers, but also for local governments and local residents. Secondly, even if such awareness does exist, it is often the case that neither local governments nor local tourist enterprises (which are usually small or medium-sized) have sufficient resources to conduct research themselves, and partnership in this respect is still rare. Thirdly, as has already been stressed, the results of some analyses show that satisfaction does not always result in customer loyalty (Taylor, 1998; Oliver, 1999). This seems particularly feasible in terms of the tourist - destination relation, given that in many segments of tourism there are strong reasons to visit new, different places every trip. Hence, a high level of satisfaction does not guarantee a visitor's return. Yet, as this article has attempted to show, loyalty is not limited to return visits. A very important issue is the dissemination of positive opinions about the destination by satisfied tourists, and this subsequently translates into an increase in income and economic development. 
The authors declare their intent to conduct further research in this area, in particular into ways of identifying key accounts, i.e. those worth striving for on the visitor loyalty front.

\section{NOTES}

1. Event tourism has been defined as the 'systematic planning, development and marketing of festivals and special events as tourist attractions, catalysts, and image builders' (Getz \& Wicks, 1993, p. 2).

2. Manager of the research: professor J. Berbeka, team members: Z. Borek, K. Borodako, K. Lipecki, A. Niemczyk, M. Rudnicki, J. Sala, R. Seweryn, D. Ziarkowski.

3. In order to calculate a synthetic evaluation of the city, the rules of multidimensional comparative analysis were used. For each respondent, positive assessments were treated as stimulants by awarding them points, respectively: for 'very good' +2 , and for 'good' +1 . Negative assessments, on the other hand, treated as destimulants, were awarded, respectively, -2 for 'very bad' and -1 for 'bad'. The assessments in between were omitted as neutral (nominants) (Niemczyk \& Seweryn, 2009). The arithmetic mean was calculated from the assessment grades awarded by all the respondents $\left(m_{i}\right)$ and $m_{s}$ (as the arithmetic mean from $m_{i}$ increased by a standard deviation of $m_{i}$ grades) and $m_{r}$ (as the arithmetic mean from $m_{i}$ decreased by a standard deviation of $m_{i}$ grades). Finally, visitors were divided into three classes using the following procedure:

- one: dissatisfied tourists, i.e. those for whom the relation $z_{i} \leq m_{r}$ occurs,

- two: satisfied tourists, i.e. those for whom the relation $m_{r}<z_{i}<m_{s}$ occurs,

- three: delighted tourists, i.e. those for whom the relation $z_{i} \geq m_{s}$ occurs.

\section{REFERENCES}

Bos, H. (1994), The importance of mega-events in the development of tourism demand, Festival Management and Event Tourism, 2(1), pp. 55-58.

Burgan, B., \& Mules, T. (2001), Reconciling cost-benefit and economic impact assessment for event tourism, Tourism Economics, 7(4), pp. 321-330.

Burns, J., Hatch, J., \& Mules, T. (Eds.) (1986), The Adelaide Grand Prix: The impact of a special event, Adelaide: The Centre for South Australian Economic Studies.

Chan, L.K., Hui, Y.V., Lo, H.P., Tse, S.K., Tso G.K.F., \& Wu M.L. (2003), Consumer satisfaction index: New practice and findings, European Journal of Marketing, 37(5/6), pp. 872-909.

Cheverton, P. (2004), Key account management: A complete action kit of tools and techniques for achieving profitable key supplier status, London: Kogan Page.

Chi, C.G.-Q., \& Qu, H. (2008), Examining the structural relationships of destination image, tourist satisfaction and destination loyalty, Tourism Management, 29(4), pp. 624-636.

Cole, S., \& Scott, D. (2004), Examining the mediating role of experience quality in a model of tourist experiences, Journal of Travel and Tourism Marketing, 16(1), pp. 77-88.

Crompton, J., \& MacKay, S.L. (1994), Measuring the economic impact of festivals and events: Some myths, misapplications and ethical dilemmas, Festival Management and Event Tourism, 2(1), pp. 33-43.

Dann, G. (1996), Tourist images of a destination. An alternative analysis, In D.R. Fesenmaier, J.T. O’Leary \& M. Uysal (Eds.), Recent adventures in tourism marketing research, New York, NY: The Haworth Press.

Davidson, R., \& Rogers, T. (2006), Marketing destinations and venues for conferences, conventions and business events, Oxford: Elsevier Ltd. 
Doyle, P. (2000), Value-based marketing: Marketing strategies for corporate growth and shareholder value, Chichester: John Wiley \& Sons.

Eriksson, K., \& Vaghult, A.L. (2000), Customer retention, purchasing behavior and relationship substance in professional services, Industrial Marketing Management, 29(4), pp. 363-372.

European Travel Commission (2006, September), Tourism trends for Europe. Retrieved from European Travel Commission website: http://www.etc-corporate.org/reports/tourism-trends, access date: 2013.09.09.

Fornell, C. (1992), A national customer satisfaction barometer: The Swedish experience, Journal of Marketing, 56(1), pp. 6-21.

Fornell, C., Johnson, M.D., Anderson, E.W., Cha, J., \& Bryant, B.E. (1996), The American customer satisfaction index: Nature, purpose, and findings, Journal of Marketing, 60(4), pp. 7-18.

Gaworecki, W.W. (2003), Turystyka [Tourism], Warsaw: PWE.

Getz, D. (1991), Festivals, special events, and tourism, New York, NY: Van Nostrand Reinhold.

Getz, D. (1994), Event tourism: Evaluating the impacts, In J. Ritchie \& C. Goeldner (Eds.), Travel, tourism, and hospitality research (pp. 437-450), New York, NY: John Wiley \& Sons.

Getz, D. (2000), Festivals and special events: Life cycle and saturation issues, In W. Gartner \& D. Lime (Eds.), Trends in outdoor recreation, leisure and tourism (pp. 175-185), Wallingford UK: CABI.

Getz, D. (2008), Event tourism: Definition, evolution, and research, Tourism Management, 29(3), pp. 403-428.

Getz, D. (2010), The nature and scope of festival studies, International Journal of Event Management Research, 5(1), pp. $1-47$.

Getz, D., \& Wicks, B. (1993), Editorial, Festival Management and Event Tourism, 1(1), pp. 1-3.

Gronroos, C. (2001), Service management and marketing, Chichester: John Wiley \& Sons.

Hall, C. (1992), Hallmark tourist events: Impacts, management and planning, London: Belhaven Press.

Kavaratzis, M., \& Ashworth, G.J. (2005), City branding: An effective assertion of identity or a transitory marketing trick? Tijdschrift voor Economische en Sociale Gegrafie, 96(5), pp. 506-514.

Kim, S.S., \& Morrsion, A.M. (2005), Change of images of South Korea among foreign tourist after the 2002 FIFA World Cup, Tourism Management, 26(2), pp. 233-247.

Kim, H.J., Gursoy, D., \& Lee, S.B. (2006), The impact of the 2002 World Cup on South Korea: Comparisons of preand post-games, Tourism Management, 27(1), pp. 86-96.

Kobus, P. (2005, June), Droga od tożsamości do wizerunku marki [The way from identity to brand image], Świat Marketingu. Retrieved from http://www.swiatmarketingu.pl/index.php?rodzaj=01\&id_numer=852813, access date: 2013.09.09.

Kotler, P. (1994), Marketing. Analiza, planowanie, wdrażanie i kontrola [Marketing. The analysis, planning, implementing and supervision], Warsaw: Geberthner i S-ka.

Kotler, P., Armstrong, G., \& Cunningham, P.H. (1999), Principles of marketing, Ontario: Prentice Hall Canada.

Kotler, P., \& Gertner, D. (2002), Country as brand, product, and beyond: A place marketing and brand management perspective. Journal of Brand Management, 9(4/5), pp. 249-262.

Kozak, M., \& Rimmington, M. (2000), Tourist satisfaction with Mallorca Spain, as an off-season holiday destination, Journal of Travel Research, 38(1), pp. 260-269.

Lau, L.S., \& McKercher, B. (2004), Exploration versus acquisition: A comparison of first-time and repeat visitors, Journal of Travel Research, 42(3), pp. 279-285.

Milman A., \& Pizam, A. (1995), The role of awareness and familiarity with a destination. The Central Florida case, Journal of Travel Research, 33(3), pp. 21-27.

Moscardo, G. (2007), Analyzing the role of festivals and events in regional development, Event Management, 11(1/2), pp. 23-32.

Mules, T., \& Faulkner, B. (1996), An economic perspective on special events, Tourism Economics, 2(2), pp. 107-117. 
Murphy, P., Pritchard, M.P., \& Smith, B. (2000), The destination product and its impact on traveller perceptions, Tourism Management, 21(1), pp. 43-52.

Niemczyk, A. (2001), The role of events in the promotion of cities and regions, In S. Hittmár (Ed.), Theory of management 4. The selected problems for the development support of management knowledge base (pp. 271-275), Zilina: University of Zilina and Institute of Management by University of Zilina.

Niemczyk, A., \& Seweryn, R. (2009), Jakość usług tworzących produkt turystyczny obszaru w opinii klientów (na przykładzie Krakowa) [Quality of services contributing to a tourist product as perceived by the customers (an example of Krakow)], In I. Rudawska \& M. Soboń (Eds.), Przedsiębiorstwo i klient w gospodarce opartej na ustugach [The company and customer in an economy based on services] (pp. 353-361), Warsaw: Difin.

O'Connor, S.J., Shewchuk, R.M., \& Carney, L.W. (1994), The great gap. Physicians' perceptions of patient service quality expectations fall short of reality, Journal of Health Care Marketing, 14(2), pp. 32-39.

Oliver, R.L. (1980), A cognitive model of the antecedents and consequences of satisfaction decisions, Journal of Marketing Research, 17(4), pp. 46-49.

Oliver, R.L. (1999), Whence consumer loyalty? Journal of Marketing, 63(3), pp. 33-44.

Preuss, H. (2007), The conceptualisation and measurement of mega sport event legacies, Journal of Sport and Tourism, 12(3-4), pp. 207-227.

Reichheld, F.F. (2006), The ultimate question, Boston: Harvard Business School Press.

Ribeiro J.C., Viseu, J., Delalande, T., \& Rodrigues, C. (2004), UEFA Euro 2004 visitors analysis, Braga: University of Minho.

Ritchie, J.R.B. (1984), Assessing the impacts of hallmark events: conceptual and research issues, Journal of Travel Research, 23(1), pp. 2-11.

San Martin, H., \& del Bosque, I.A. (2008), Exploring the cognitive-affective nature of destination image and the role of psychological factors in its formation, Tourism Management, 29(2), pp. 263-277.

Seweryn, R. (2012), Kreowanie wartości dla klienta przez obszar recepcji turystycznej [The creation of customer value by tourism areas], Krakow: Wydawnictwo Uniwersytetu Ekonomicznego w Krakowie.

Taylor, T.B. (1998), Better loyalty measurement leads to business solutions, Marketing News, 32(22), pp. 41-42.

Yoon, Y., \& Uysal, M. (2005), An examination of the effects of motivation and satisfaction on destination loyalty: A structural model, Tourism Management, 26(1), pp. 45-56. 